\title{
Failing Together in Solidarity
}

Alexandra Novitskaya

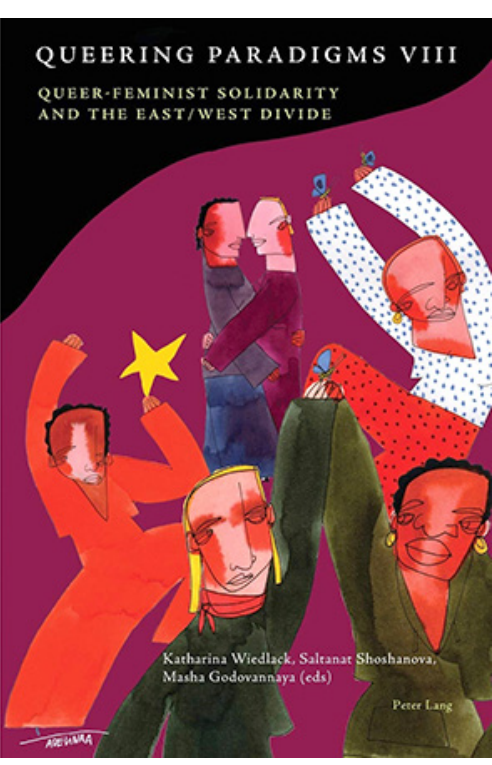

Wiedlack, Katharina, Saltanat Shoshanova, and Masha Godovannaya, eds. 2020. Queering Paradigms VIII: QueerFeminist Solidarity and The East/West Divide. Peter Lang UK. 382 pages. https://doi.org/10.3726/b14797.

Queer-Feminist Solidarity and the East/ West Divide, edited by Katharina Wiedlack, Saltanat Shoshanova, and Masha Godovannaya, is a timely anthology that addresses transnational solidarity between Western queer and feminist communities and their counterparts in postsocialist Central and Eastern Europe and Eurasia (CEE \& E). Solidarity is a foundational concept in the scholarship on social movements; and the volume's contributors put it under an analytical microscope as they investigate the complexity, legitimacy, and value of "West-East" solidarity efforts which, due to such intertwined processes as the continuing EU expansion eastward, the rise of right-wing "antigender" movements, and the geopolitical instrumentalization of homophobia in CEE \& E, have been a prominent feature of the past decade.
The volume's fourteen engaging, if uneven chapters, written by twenty academics and activists, cover impressively diverse topics. They include studies of Russian LGBTQ refugees; artistic responses to sexism, homoand transphobia; contestations of pride parades; new interpretations of Orthodox Christianity's views on homosexuality; and challenges to Western representations of queer CEE \& E. Some chapters are didactic in tone and evoke images of righteous in-fighting endemic to scholar-activist communities at the vanguard of cutting-edge queer critique. Others present state-of-research reports - unsurprisingly so, given the novelty of their topics. All fourteen chapters do an excellent job diversifying the "East" and illuminating the heterogeneity of its queer and feminist activist communities. Also unsurprisingly, the anthology's collective critique leaves some important issues unaddressed.

In the opening chapter "Fucking Solidarity: 'Working Together' Through (Un)pleasant Feelings," one of the editors Katharina Wiedlack offers up her vision of international queer solidarity. Careful to distinguish her project from empathy-based moral solidarity or identity politics, she suggests that successful solidarity work emerges out of shared affective labor ("working together") grounded in sharing resources and privileges (44). Unlike charity, this avoids the pitfalls of treating the subjects of solidarity as victims while still recognizing their oppression. Owing to a personal history of affective, romantic, and intimate connections to post-Soviet
Queer Eye Reviews

Alexandra Novitskaya 
LGBTQ subjects and spaces, Wiedlack has been involved in queer-feminist activism and solidarity-building work for several years. This chapter, part critical auto-ethnographic reflection and part theoretical conceptualization of effective solidarity efforts, is the result of this experience. Explicitly critical and deeply suspicious of Western visibility-centered solidarity acts such as public protests or online campaigns, which to her only reproduce "East-West divides," Wiedlack discusses her own involvement in solidarity activism which resulted in a series of activist-academic events she had helped organize in Austria in 2013-2017. Addressing the difficulties with these events, such as irreparable disagreements between some participants, Wiedlack argues that failure is not only an inevitable part of any solidarity project; it should be a welcome and expected outcome.

As someone who attended one of the events discussed in the chapter and even witnessed first-hand some of the incidents Wiedlack uses to theorize failure as a necessary part of solidarity effort, I agree with her on the importance of sharing material resources and promoting equality in solidarity work. However, the events in question were not examples of "solidarities of everyday"(22): like all other conferences or festivals, they were singular events with specific aims and audiences; they demanded careful planning and significant resources, and operated within a closed temporality, having had a fixed beginning and a fixed end. Like all cultural or educational events, they may or may not have a lasting impact on participants, let alone a wide outreach. Which leads to the following questions: how do you practice queer solidarity with people you have not met, and may never meet in person? People you are not attracted to? People whose lifestyles and social location are on the opposite end of your own? This is where wide online and offline solidarity activism, labeled by Wiedlack and other contributors as "Western," might be productive. Still, Wiedlack's interrogation of solidarity should be recommended to anyone who considers themselves an ally.
Overall, Queer-Feminist Solidarity reads as a spiritual successor to Joanna Mizielińska and Roberto Kulpa's 2011 collection De-Centering Western Sexualities: Central and Eastern European Perspectives which approaches Central and Eastern European LGBTQ politics through the prism of the postcolonial critique, thus challenging Eurocentrism. Seven out of fourteen essays reference Mizielińska and Kulpa's anthology, and even the very wording of the book's subtitle - the "East/West Divide" - appears to be an homage to the former. While an important intervention, Mizielińska and Kulpa's critique, and the resulting scholarship it has inspired have been questioned as perpetuating the discursive binaries they had aimed to deconstruct (Navickaite 2014). Likewise, the critical approach signaled by Queer-Feminist Solidarity's editorial perspective might inadvertentlyeven paradoxically—reinforce the very discursive structures it seeks to challenge. In its analysis of the Western framing of the "East" as always victimized and the "West" as always self-serving, it risks producing monolithic, essentializing portrayals of both "East" and "West," rather than problematizing the very binary or capturing the complexity of feminist and LGBTQ activism in both locations. Although most essays in the volume mitigate this risk, presenting the queer "East" as a heterogeneous space full of conflicting perspectives and contested ideologies, this perspective does not come clear in the volume editorial, rather reinforcing the "East/ West divide."

Besides, left unaddressed is the Russia hegemony within post-Soviet and postsocialist feminist and queer studies. Post-Soviet, rather than postsocialist subjects and localities dominate the volume: eleven chapters are dedicated to post-Soviet queer politics with eight being about Russia. The only two postsocialist (not post-Soviet) subjects are addressed by Veda Popovici and Joanna Chojnicka in chapters about Romanian pride politics, and Polish trans blogs, respectively. Also left unexplored is solidarity within the postsocialist and post-Soviet spaces/the "East": 
how can solidarity be practiced across the borders and boundaries within CEE \& E? Are visibility-based solidarity campaigns, even if practiced by "local" activists, always already "Western"? What about multiple ingroup tensions experienced by post-Soviet and postsocialist feminists and LGBTQ communities, such as transphobia in feminist circles or the (absence) of anti-war and anti-militarist solidarity between Ukrainian and Russian feminist and queer activists?

Finally, the volume could have incorporated more theoretical literature on transnational queer and feminist solidarity such as works by Atshan (2020), Dean (1997), Gunkel (2013), and others; and historic examples of other successful solidarity work between Western and Eastern feminists and/or LGBTQ communities, such as the well-documented Network of East-West Women (NEWW), which was founded in the early 1990s by Central and Eastern European and American feminists and, fueled by solidarity, has sustained productive collaborations between its American and Eastern-European members for over twenty-five years (Snitow 2020).

As such, Queer-Feminist Solidarity is an important addition to the growing area of postsocialist and post-Soviet queer and feminist studies. The volume's contributions to post-Soviet queer migration studies are especially promising: the three chapters about queer post-Soviet migration and refugees in Germany, France, and transnationally, expand and enrich both geographic and analytical dimensions of this scholarship. This, combined with the diversity of perspectives and subjects introduced by the volume contributors, makes Queer-Feminist Solidarity a necessary read for anyone interested in contemporary post-Soviet queer politics and transnational solidarity activism.

\section{References}

Atshan, Sa'ed. 2020. Queer Palestine and the Empire of Critique. Stanford: Stanford University Press.

Dean, Jodi. 1997. "Feminist Solidarity, Reflective Solidarity: Theorizing Connections after Identity Politics.” Women \& Politics, 18(4): 1-26.

Gunkel, Henriette. 2013. "Some Reflections on Postcolonial Homophobia, Local Interventions, and LGBTI Solidarity Online: The Politics of Global Petitions." African Studies Review, 56(2): 67-81.

Kulpa, Roberto, and Mizielińska, Joanna, ed. 2011. De-Centring Western Sexualities: Central and Eastern European Perspectives. Burlington: Ashgate.

Navickaite, Rasa. 2014. "Postcolonial Queer Critique in Post-communist Europe: Stuck in the Western Progress Narrative?" Tijdschrift Voor Gender Studies, 17(2): 167-185.

Snitow, Ann. 2020. Visitors: An American Feminist in East Central Europe. New York: New Village Press. 